\title{
PEMANFAATAN TUMBUHAN SEKITAR SEBAGAI OBAT TRADISIONAL BAGI WARGA DESA PUUNDOHO KAB. KOLAKA UTARA
}

\author{
Hasria Alang ${ }^{1}$, Hastuti ${ }^{2}$,Muh. Sri Yusal ${ }^{3}$ \\ Biologi, STKIP-PI, Makassar, Indonesia \\ Email: hasriaalangbio@gmail.com
}

\begin{abstract}
Medicinal plants are all species of medicinal plants that are known and believed to have traditional medicinal properties so that they can be used as self-medicated efforts. Puundoho village is a village located in the district. North Kolaka, Southeast Sulawesi. The majority of villagers have large yards and gardens because the villagers are generally farmers. The yard as the environment provides various natural resources that have not been optimally utilized, one of which is the use of surrounding plants. Many plants whose roles are unknown as traditional medicine. This causes the population to depend heavily on chemical drugs even if it is only for treating minor ailments. In addition, these plants are considered weeds and so are often destroyed, either by spraying herbicides or by cutting them down. This will certainly disrupt the ecosystem and diversity of plants in this environment. The condition of the Puundoho Village community's ignorance is the reason for this community service. The purpose of this activity is to optimize the role of plants around as an effort to self-medicate and to support the public interest "back to nature". The method used in this activity is community development using lectures which is educational for participants consisting of several villagers. The results of the service showed that there was an increase in the knowledge of the village community who were present at the service activity regarding the use of surrounding plants as traditional medicine. This can be seen from the ability of the participants to answer questions from the implementation team.
\end{abstract}

\section{Keywords: Optimization, medicinal plants, self-medication}

\begin{abstract}
Abstrak
Tumbuhan obat adalah seluruh spesies tumbuhan obat yang diketahui dan dipercaya mempunyai khasiat sebagai obat secara tradisional sehingga dapat digunakan sebagai upaya pengobatan mandiri. Desa Puundoho adalah salah satu desa yang terletak di Kab. Kolaka Utara, Sulawesi Tenggara. Mayoritas penduduk desa memiliki pekarangan dan kebun yang luas dikarenakan penduduk desa umumnya adalah petani. Pekarangan sebagai lingkungan hidup menyediakan berbagai sumber daya alam yang belum dimanfaatkan secara optimal, salah satunya adalah pemanfaatan tumbuhan sekitar. Banyak tumbuhan yang belum diketahui peranannya sebagai obat tradisional. Hal ini menyebabkan penduduk sangat tergantung pada obat-obatan kimia
\end{abstract}


meskipun hanya untuk menangani penyakit ringan saja. Selain itu, tumbuhan tersebut dianggap gulma sehingga acapkali dimusnahkan, baik dengan penyemprotan herbisida ataupun dengan pembabatan. Hal ini tentu akan mengganggu ekosistem serta diversitas tumbuhan di lingkungan ini. Kondisi ketidaktahuan masyarakat Desa Puundoho, menjadi alasan dilakukannya pengabdian masyarakat ini. Tujuan kegiatan ini adalah untuk mengoptimalkan peranan tumbuhan yang ada disekitar sebagai upaya pengobatan mandiri serta untuk mendukung animo masyarakat "bact to nature". Metode yang digunakan pada kegiatan ini adalah menggunakan ceramah yang sifatnya mengedukasi para peserta yang terdiri dari beberapa warga desa. Hasil pengabdian menunjukkan bahwa terjadi peningkatan pengetahuan masyarakat desa yang hadir pada saat kegiatan pengabdian tentang pemanfaatan tumbuhan sekitar sebagai obat tradisional. Hal ini terlihat dari kemampuan para peserta untuk menjawab pertanyaan dari tim pelaksana.

\section{Kata Kunci: Optimalisasi, Tumbuhan obat, Pengobatan mandiri.}

\section{A. PENDAHULUAN}

Pengobatan mandiri (sendiri) adalah kegiatan atau tindakan mengobati diri sendiri dengan obat atau tanpa resep secara tepat dan bertanggung jawab (rasional) (Rahim, dkk., 2013). Dalam kehidupan sehari-hari, banyak penyakit dan gangguan kesehatan dapat dikenali dan diobati secara mandiri (pengobatan mandiri) baik oleh penderita maupun oleh orang di sekitarnya. Hal ini dianggap lebih hemat waktu dan biaya daripada apabila penderita harus pergi ke dokter. Namun, acapkali pengobatan mandiri menimbulkan masalah dikarenakan kurangnya pengetahuan tentang obat-obatan (Harahap, dkk., 2017). Pengobatan mandiri dapat dilakukan dengan memanfaatkan tumbuhan obat disekitar. Tumbuhan obat yaitu seluruh spesies tumbuhan yang diketahui atau dipercaya mempunyai khasiat obat yaitu menghilangkan rasa sakit, meningkatkan daya tahan tubuh, membunuh bibit penyakit, dan memperbaiki organ yang rusak serta menghambat tumor dan kanker (Zuhud, 2004, Dalimartha, 2007; Yulianti, 2009; Nurmayulis \& Hernita, 2015; Radam, dkk., 2016).

Desa Puundoho adalah salah satu desa yang terletak di Kab. Kolaka Utara, Sulawesi Tenggara. Mayoritas penduduk desa memiliki pekarangan dan kebun yang luas dikarenakan penduduk desa umumnya adalah petani. Pekarangan sebagai lingkungan hidup menyediakan berbagai sumber daya alam yang belum dimanfaatkan secara optimal, salah satunya adalah pemanfaatan tumbuhan sekitar. Banyak tumbuhan yang belum diketahui peranannya sebagai obat tradisional. Hal ini menyebabkan penduduk sangat tergantung pada obat-obatan kimia meskipun hanya untuk menangani penyakit ringan saja. Padahal pemanfaatan tumbuhan sebagai obat tradisional selain aman karena tidak menimbulkan efek samping, juga dapat mengurangi kebergantungan terhadap obat sehingga mengurangi pengeluaran dana untuk pembelian obat. Peningkatan pengetahun dan sikap masyarakat dapat dilakukan dengan upaya pemberian informasi misalnya penyuluhan atau edukasi. Pengobatan penyakit secara mandiri perlu dilakukan guna membantu program pemerintah untuk mencerdaskan bangsa dan meningkatkan derajat kesehatan. Selain itu, banyak tumbuhan yang dianggap gulma acapkali dimusnahkan, baik dengan penyemprotan herbisida ataupun dengan pembabatan. Hal ini tentu akan mengganggu ekosistem tumbuhan di lingkungan ini.

Kondisi ketidaktahuan masyarakat tentang jenis tumbuhan sekitar sebagai sumber obatobatan guna pengobatan mandiri penyakit memberikan pemahaman perlunya diadakan 
kegiatan pengabdian masyarakat berupa penyuluhan dan edukasi terkait pemanfaatan tumbuhan sekitar yang berperan sebagai obat-obatan. Kegiatan pengabdian masyarakat ini berupa ceramah, yang sifatnya mengedukasi para peserta yang terdiri dari beberapa warga desa. Edukasi ini berfungsi untuk meningkatkan pengetahuan dan pemahaman warga desa tentang tumbuhan sekitar yang dapat digunakan sebagi obat-obat tradisional. Hal ini dimaksudkan untuk mendukung animo masyarakat "bact to nature", serta mengoptimalkan peranan tumbuhan yang ada disekitar sebagai upaya pengobatan mandiri.

\section{B. METODE PELAKSANAAN}

Pelaksaan kegiatan pengabdian masyarakat ini dilakukan selama satu hari penuh, yaitu pada tanggal 20 September 2020 di gedung pertemuan Desa Puundoho, Kecamatan Pakue Utara Kabupaten Kolaka Utara, Sulawesi Tenggara. Tahapan kegiatan ini terdiri atas dua tahap, yaitu:

1. Tahap awal, meliputi :

a. Survei atau observasi ke tempat yang akan dijadikan sebagai objek kegiatan pengabdian masyarakat. Survei ini berfungsi untuk mendapatkan informasi terkait pengetahuan masyarakat ditempat tersebut, terkait pengobatan mandiri berbahan tumbuhan sekitar. Hal ini dimaksudkan untuk mensukseskan kegiatan pengabdian masyarakat nantinya

b. Perizinan kepada mitra, tim pengabdian melakukan perizinan kepada mitra sekaligus memastikan jadwal pelaksaan pengabdian

c. Koordinasi internal antar tim pengabdian, berupa pembuatan proposal dan pembagian job desk

2. Tahap pelaksanaan, meliputi

a. Perkenalan tim pengabdian yang dilakukan oleh kepala desa setempat sebagai ketua mitra.

b. Pemaparan tujuan kegiatan oleh salah satu tim pengabdian

c. Tanya jawab terkait pemanfaatan tumbuhan pekarangan sebagai stimulus dan mengukur pengetahuan dasar para peserta

d. Penyampaian materi menggunakan metode ceramah yang sifatnya mengedukasi para peserta. Edukasi yang dilakukan berupa upaya pengobatan mandiri menggunakan tumbuhan sekitar. Nama tumbuhan, manfaat serta cara pengolahan berdasarkan Taksonomi Tumbuhan Obat-obatan oleh Tjitrosoepomo, (2005) serta buku Flora oleh van Steenis, (2005) yang tim peroleh ketika masa kuliah dahulu.

e. Dilanjutkan tanya jawab untuk mengukur pengetahuan dan pemahaman para peserta (dimaksudkan untuk melihat bagaimana memori para peserta setelah mendengar pemaparan dari salah satu tim yang bertindak sebagai pembawa materi)

\section{HASIL DAN PEMBAHASAN}

\section{Tahap Awal}

Survei yang telah dilaksanakan sekaligus medapatkan data terkait jenis tanaman yang banyak disekitar tempat tinggal warga, terlihat pada gambar 1. Hasil survei tersebut, rata-rata warga menyatakan bahwa tanaman yang mereka sebutkan hanyalah semata-mata gulma sehingga wajib dibasmi. 


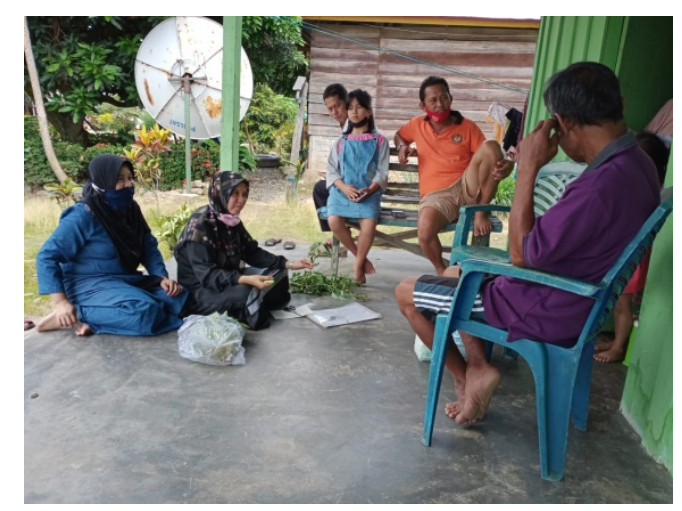

Gambar 1. Observasi dan wawancara

\section{Tahap Pelaksanaan}

Sesuai dengan jadwal kegiatan yang telah direncanakan sebelumnya, maka kegiatan ini dibuka secara resmi oleh kepala desa Puundoho yang sangat mengapresiasi kegiatan ini. Kegiatan ini dilaksanakan di gedung pertemuan Desa Puundoho dan dihadiri oleh warga (gambar 2).

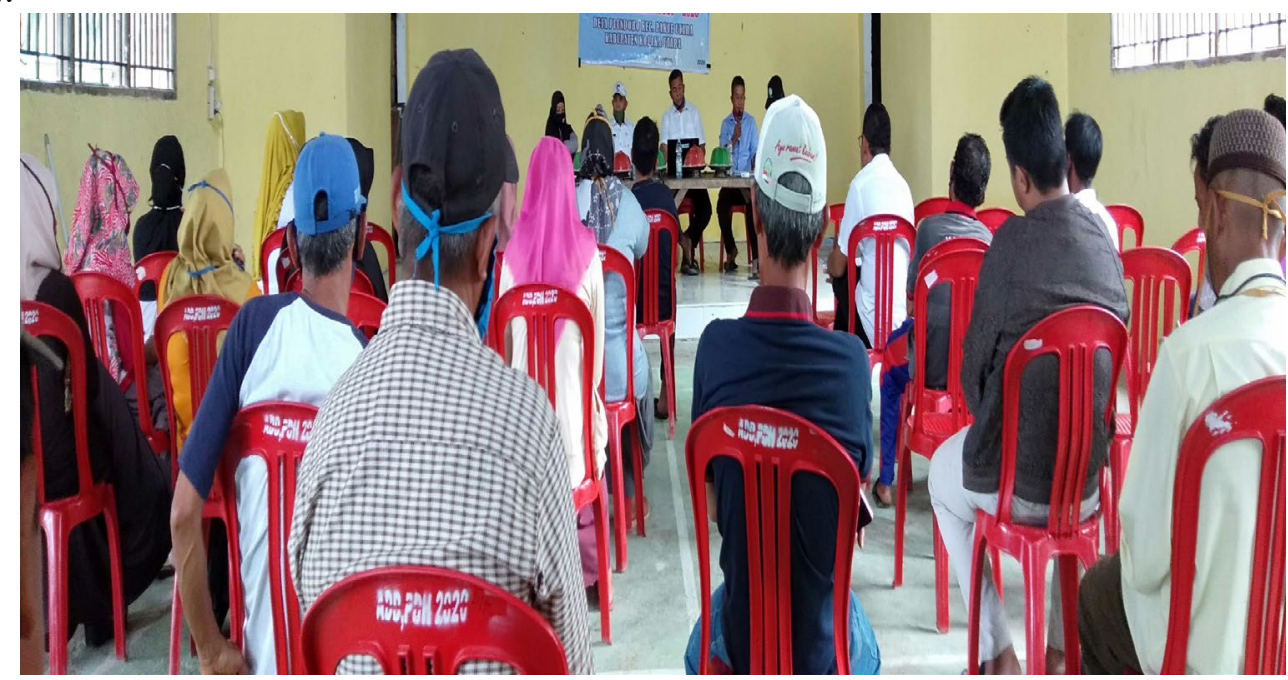

Gambar 2. Acara pembukaan kegiatan pengabdian masyarakat

Pelaksanaan kegiatan masyarakat ini bertujuan untuk mengedukasi masyarakat tentang tumbuhan sekitar yang dapat dimanfaatkan sebagai upaya pengobatan mandiri atau pengobatan sendiri. Edukasi dilakukan berupa ceramah (gambar 3), selanjutnya pemateri menyampaikan jenis tanaman serta peranan atau manfaatnya bagi kesehatan Pelaksanaan kegiatan pengabdian ini diikuti para peserta dengan sangat antusias. Pada tahap diskusi, pemateri kemudian menyebutkan beberapa tanaman pekarangan beserta cirinya yang memiliki manfaat. Peserta dipersilahkan menyebut nama tanaman tersebut berdasarkan nama daerah. Diakhir kegiatan, dilakukan tanya jawab. Hal ini berfungsi untuk melihat seberapa besar daya tangkap para peserta tentang jenis tanaman yang telah dipaparkan sebelumnya (tabel 1 dan gambar 4). 


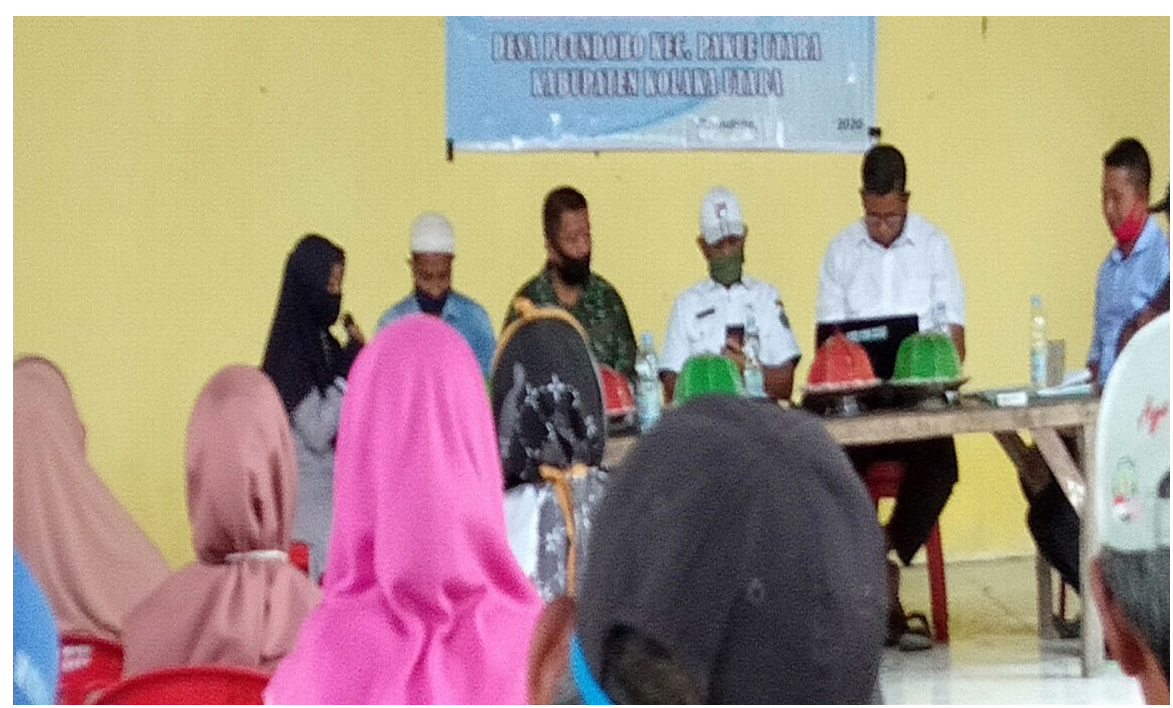

Gambar 3. Pemaparan materi oleh Tim Pengabdian Masyarakat

Tabel 1. Beberapa tanaman beserta jawaban peserta pengabdian

\begin{tabular}{llll}
\hline No. & $\begin{array}{l}\text { Nama } \\
\text { tanaman }\end{array}$ & Manfaat & $\begin{array}{l}\text { Nama lokal (jawaban } \\
\text { peserta) }\end{array}$ \\
\hline 1. & Sirih-sirihan & Menurunkan kadar asam urat & Daun kaca-kaca \\
2. & Meniran & Untuk infeksi saluran kemih & Sibokorang \\
3. & Krokot & Mengobati penyakit jantung & Lengngalo \\
4. & Kitolod & Mengobati pembengkakan pada & Barakati \\
& & kelopak mata & \\
\hline
\end{tabular}

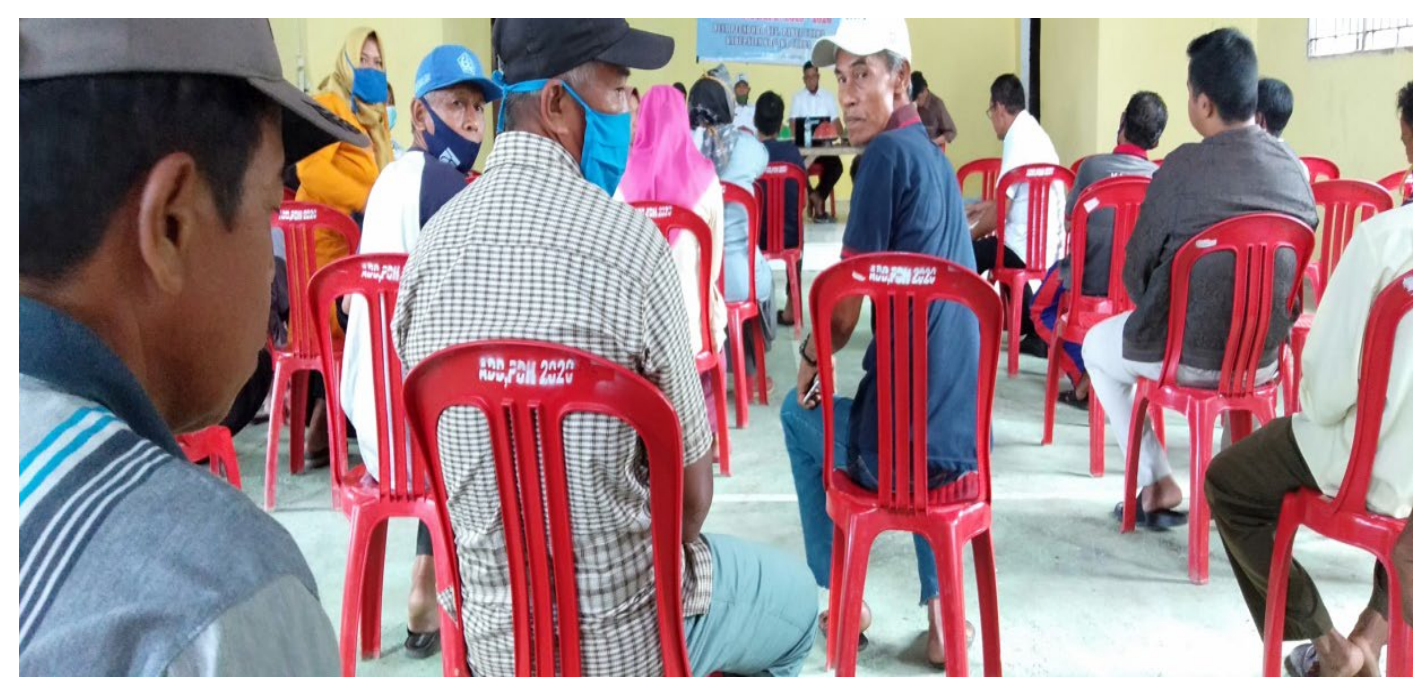

Gambar 3. Sesi Tanya jawab tim pelaksana dengan para peserta 
Dari hasil penyuluhan yang telah dilakukan, maka diperoleh hasil bahwa terjadi peningkatan pengetahuan para peserta terkait pengobatan mandiri dengan memanfaatkan bahan alam yang ada disekitar. Indikator Keberhasilan kegiatan pengabdian ini terlihat dari adanya kemampuan para peserta untuk menjawab pertanyaan dari tim pelaksana

\section{KESIMPULAN DAN SARAN}

\section{Kesimpulan}

Edukasi tentang penggunaan obat tradisional berbahan tumbuhan sekitar merupakan langkah awal dalam meningkatkan pengetahuan dan pemahaman warga desa tentang pengobatan mandiri dengan memanfaatkan lingkungan skitar. Kegiatan pengabdian masyarakat ini membawa dampak telah terjadi penigkatan pengetahuan para peserta. Kedepannya, para peserta pengabdian masyarakat ini perlu dilakukan follow-up untuk melihat perubahan perilaku setelah mendapatkan pengetahuan tentang tumbuhan sekitar yang dapat dijadikan sebagi obat-obatan tradisional.

\section{Saran}

Diharapkan dengan adanya kegiatan pengabdian masyarakat ini, mitra bisa memanfaatkan jenis tumbuhan sekitar untuk upaya pengobatan mandiri guna mengurangi kebergantungan pada obat sehingga meringankan beban ekonomi keluarga serta dapat melestarikan kearifan lokal ini kepada generasi berikutnya

\section{DAFTAR PUSTAKA}

Bela, A., Suryawati, S., \& Rustamaji. (2016). Intervensi CBIA untuk Meningkatkan Pengetahuan, Sikap, dan Perilaku Penggunaan Antibiotik yang Rasional pada Anggota Bina Keluarga Balita CBIA. Jurnal Kedokteran Brawijaya, 29(2), 165- 169.

Dalimartha, S. (2007). Atlas Tumbuhan Obat Indonesia. Retrieved from https://doi.org/10.1017/s175173110800373x.259.

Harahap, N. A., Khairunnisa, \& Tanuwijaya, J. (2017). Tingkat Pengetahuan Pasien dan Rasionalitas Swamedikasi di Tiga Apotek Kota Panyabungan. Jurnal Sains Farmasi \& Klinis, 3(2), 186-192.

Departemen Kesehatan RI. (2007). Pedoman Penggunaan Obat Bebas dan Bebas Terbatas. Jakarta: Departemen Kesehatan RI.

Nurmayulis \& Hermita, N. (2015). Potensi tumbuhan obat dalam upaya pemanfaatan lahan pekarangan oleh masyarakat desa Cimenteng kawasan Taman Nasional Ujung Kulon. Agrologia, 4(1), 1-7.

Radam, R., Soendjoto. M.A., \& Prihatiningtyas, E. (2016). Pemanfaatan tumbuhan yang berkhasiat obat oleh masyarakat di Kabupaten Tanah Bumbu Kalimantan Selatan. Prosiding Seminar Nasional Lahan Basah, (2): 486 - 492.

Rahim, Kandowangko, \& Uno. (2013). Identifikasi Tumbuhan Berkhasiat Obat yang Digunakan oleh Pengobatan Tradisional di Suku Bajo di Desa Torosiaje. Laporan Penelitian. Fakultas MIPA Universitas Negeri Gorontalo.

Tjitrosoepomo, G. (2005). Taksonomi Tumbuhan Obat-obatan. Cetakan ke-2. Yogyakarta. Gadjah Mada University Press.

Van-Steenis, C. G. G. J. (2005). Flora. Jakarta: Pradnya Paramita. 
Yulianti, E. (2009). Peran Tanaman Obat sebagai Agen Antikanker. Seminar Nasional Biologi Yogyakarta.

Zuhud E. A. M. \& Haryanto. 2004 Pelestarian Pemanfaatan Keanekaragaman Tumbuhan Obat Hutan Tropika 63 Indonesia. Jurusan Konservasi Sumberdaya Hutan Fakultas Kehutanan IPB, Lembaga Alam Tropika Indonesia. Bogor. 